\title{
Influence of Biperiden and Bornaprine on Sleep in Healthy Subjects
}

Fritz Hohagen, M.D., Stephanie Lis, M.A., Dieter Riemann, Ph.D., Stephan Krieger, M.A., C. Meyer, M.D., Rosemarie Fritsch Montero, M.D., Heinz Grunze, M.D., and Mathias Berger, M.D.

Biperiden, $4 \mathrm{mg}$, an anticholinergic drug that is relatively selective for the $M 1$ receptor subtype, and bornaprine, $4 \mathrm{mg}$, a nonselective M1 and M2 antagonist, were administered orally in a randomized, double-blind design to twelve healthy volunteers to investigate the effect on polysomnographically recorded sleep. Both drugs suppressed rapid eye movement (REM) sleep as reflected by an increase of REM latency and a decrease in the percentage of REM sleep period time with the effects of biperiden being more pronounced. No significant effect on slow wave sleep was observed. The results of this study support the hypothesis that both the M1 and the M2 receptor subtype are involved in the regulation of REM sleep in humans. [Neuropsychopharmacology 11:2932, 1994]
KEY WORDS: Bornaprine; Biperiden; Cholinergic system; REM sleep; Slow wave sleep

There is strong evidence that the cholinergic system is involved in the generation of rapid eye movement (REM) sleep (Hobson et al. 1986). Whereas the triggering of REM sleep by cholinergic neurons has been demonstrated convincingly (Hobson et al. 1975, 1986; Shiromani et al. 1987), it is still a question as to the extent muscarinic M1 and/or M2 receptors are involved in REM sleep regulation. Results of a recent study based on the microinjection of cholinomimetic drugs at the medial pontine-reticularformation in cats suggest that physiological and cholinergically induced REM sleep is mediated primarily by the M2 subtype of muscarinic receptors (Velazquez-Moctezuma et al. 1989, 1990). In comparison, biperiden, a preferential M1 antagonist, increased REM sleep latency, and reduced REM sleep time in healthy volunteers (Gillin et al. 1991; SalinPascual et al. 1991, 1993).

The aim of the present study was to investigate the

From the Psychiatric Department, University of Freiburg, Freiburg, D-Germany.

Address reprint requests to: Dr. F. Hohagen, Psychiatric Department of the University of Freiburg, Hauptstr. 5, W-79104 Freiburg, D-Germany.

Received November 2, 1993; revised February 15, 1994; accepted February 28, 1994. effect of biperiden and bornaprine, two cholinergic antagonists, on sleep, especially REM sleep, in healthy subjects. The pharmacokinetic properties of both drugs are similar (Hollmann et al. 1984; Grimaldi et al. 1986; Mayo et al. 1980). Biperiden is considered to be a highly selective M1 antagonist (Burke 1986; Syvälahti et al. 1988; Eltze and Figala 1988; Freedman et al., 1988) with a M1 selectivity similar to that of pirenzepine (Syvälahti et al. 1987; Avissar and Schreiber 1989; Larson et al. 1991). Bornaprine, another centrally acting anticholinergic drug, lacks selectivity for the M1 or M2 receptor having equal affinity to both receptor subtypes (Kreiskott and Kretschmar 1985). The antagonism of bornaprine at the M2 muscarinic receptor has been demonstrated (Hufford et al., 1991). If M2 receptors are mainly responsible for the generation of REM sleep, a nonselective anticholinergic drug like bornaprine, that also shows M2 antagonistic properties, should have stronger REM sleep-suppressing effects compared to a preferentialM1 receptor antagonist like biperiden.

\section{SUBJECTS AND METHODS}

We investigated 12 healthy volunteers with a mean age $( \pm S D)$ of $25.01 \pm 1.9$ years (range $22-28$ years) who 
were paid for their services. After one adaptation night, the subjects slept on night 2 , night 5 , and night 8 in the sleep laboratory. Biperiden, $4 \mathrm{mg}$, bornaprine, $4 \mathrm{mg}$, or placebo were given at 9 P.M. (i.e., two hours before the lights were turned off) on nights 2,5 , and 8 in a double-blind, randomized way. No sleep EEG recordings were performed in the drug-free nights of $3,4,6$, and 7, which served to avoid carryover effects of the drugs given on the succeeding nights. Sleep was recorded between 11.00 P.M. and 7.00 A.M. according to standard procedures (Rechtschaffen and Kales 1968).

For descriptive purposes, mean $\pm \mathrm{SD}$ were calculated. To compare placebo and drug conditions, a oneway ANOVA for repeated measurements was computed ( $d f$ corrected according to the method of Greenhouse-Geisser). For ANOVAs yielding a $p$ value $<.05$, statistical contrasts (two-tailed $t$-tests) were calculated to compare the three different conditions (placebo, bornaprine, biperiden) with each other.

\section{RESULTS}

In the ANOVA, no statistically significant effects concerning sleep continuity and sleep architecture occurred. Especially slow wave sleep(SWS) remained unchanged. Mean $\pm \mathrm{SD}$ of REM sleep variables and the results of the statistical analysis are depicted in Table 1.

Concerning a lenient definition of REM latency (i.e., time from sleep onset to the first epoch of stage REM), no statistically significant effect as calculated by ANOVA occurred. With a strict definition of REM latency (i.e., calculating the interval from the first consecutive $10 \mathrm{~min}$ of uninterrupted sleep [at least stage 2] to the first REM period, which was at least 3 min in length), a significant effect was detected. Calculations of statistical contrasts revealed that bornaprine almost significantly increased REM latency, whereas with biperiden, a significant increase of REM latency was noted. Further statistically significant effects in the ANOVA occurred for REM percent sleep period time (SPT), and total REM density (\%).

The calculation of contrasts demonstrated that all of these effects were stronger for biperiden, compared to placebo, than for bornaprine, compared to placebo. For REM percent SPT, a highly significant decrease was demonstrated for biperiden, whereas with bornaprine, the level of significance just reached $p<.05$. The duration of the first REM period was decreased significantly only with biperiden. With respect to phasic parameters of REM sleep, a significant increase of REM density of the whole night was noted with biperiden compared to placebo but not with bornaprine.

\section{DISCUSSION}

Biperiden, as well as bornaprine, suppressed REM sleep in healthy volunteers. Our results with biperiden are consistent with human pharmalogical (Salin-Pascual et al. 1991; Gillin et al. 1991) and with animal studies (Zoltoski et al. 1993), that demonstrated a dose-dependent suppression of REM sleep following the administration of biperiden. In accordance with animal data (Zoltoski

Table 1. Variables of REM Sleep (Mean \pm SD) and Statistical Analysis

\begin{tabular}{|c|c|c|c|c|c|c|c|c|c|}
\hline & \multicolumn{5}{|c|}{ ANOVA } & & \multicolumn{3}{|c|}{$t$-Tests } \\
\hline & Placebo & 1 & 2 & $\mathbf{F}$ & $p$ & & $d f$ & 3 & 4 \\
\hline $\begin{array}{l}\text { REM latency } \\
\text { (lenient def.) }\end{array}$ & $89.7 \pm 40.7$ & $126.8 \pm 47.7$ & $110.3 \pm 43.7$ & 1.65 & .215 & & $\begin{array}{r}22 \\
2\end{array}$ & & \\
\hline $\begin{array}{l}\text { REM latency } \\
\text { (strict def.) }\end{array}$ & $113.0 \pm 51.8$ & $158.8 \pm 66.3$ & $202.5 \pm 86.2$ & 5.29 & .014 & b & $\begin{array}{r}22 \\
2\end{array}$ & a & b \\
\hline REM \% SPT & $24.3 \pm 6.3$ & $19.2 \pm 6.4$ & $17.3 \pm 4.0$ & 8.29 & .002 & c & $\begin{array}{r}22 \\
2\end{array}$ & b & c \\
\hline $\begin{array}{l}\text { Duration 1st REM } \\
\text { period (min) }\end{array}$ & $19.0 \pm 10.8$ & $15.8 \pm 12.8$ & $7.2 \pm 8.8$ & 3.49 & .057 & a & $\begin{array}{r}22 \\
2\end{array}$ & & c \\
\hline $\begin{array}{l}\text { Density 1st } \\
\text { REM period (\%) }\end{array}$ & $15.1 \pm 6.4$ & $16.9 \pm 9.0$ & $19.6 \pm 14.2$ & 0.67 & .519 & & $\begin{array}{r}22 \\
2\end{array}$ & & \\
\hline $\begin{array}{l}\text { REM density (\%) } \\
\text { total }\end{array}$ & $21.5 \pm 7.5$ & $24.7 \pm 8.0$ & $29.6 \pm 6.6$ & 5.06 & .022 & b & $\begin{array}{r}22 \\
2\end{array}$ & & b \\
\hline
\end{tabular}

Drug(s): 1 = bornaprine, 2 = biperiden, 3 = placebo versus bornaprine, 4 = placebo versus biperiden, 5 = bornaprine versus biperiden.

a $p<.1$.

b $p<.05$.

${ }^{c} p<.01$. 
et al. 1993), no increase of SWS could be found under biperiden.

The main hypothesis to test was if M1 and/or M2 receptors are involved in the regulation of REM sleep in humans. If $\mathrm{M} 2$ receptors are responsible for triggering REM sleep, as proposed by Velazquez-Moctezuma et al. $(1989,1990)$ based on animal data, the nonselective M1 and M2 antagonist bornaprine was supposed to have a stronger REM sleep-suppressing effect compared with the selective M1 antagonist biperiden. In contrast to this assumption, the M1 antagonist biperiden showed a stronger REM sleep-suppressing effect compared with the nonselective cholinergic antagonist bornaprine. Several explanatory factors should be considered.

First, although biperiden is a highly selective M1 antagonist comparable to pirenzepine (Syvälahti et al. 1987; Avissar and Schreiber 1989), the drug also has weak antagonistic effects on the $\mathrm{M} 2$ receptor. Thus, the possibility cannot totally be eliminated that at higher doses, biperiden may act also on the M2 receptor. Nevertheless, $4 \mathrm{mg}$ of biperiden appear to be a low dose and the REM sleep-supressing effect of the nonselectiveM1/M2 antagonist bornaprine was lower. Restricting speculations, comparative studies in animals on the central nervous effect of both drugs are lacking, and we are not aware if both drugs have comparable central nervous activity at the same dose of $4 \mathrm{mg}$.

Second, as pointed out by Zoltoski et al. (1993), the hypothesis that REM sleep was triggered by M2 muscarinic receptors arose from studies in which relatively selective muscarinic agonists and antagonists were applied to the medial pontine reticular formation (Hobson et al. 1986; Shiromani et al. 1987). Thus, it might be that other anatomical sites, including those with M1 receptors, can modify or modulate the onset, maintenance, or nature of REM sleep (Zoltoski et al. 1993).

To summarize, our study confirms earlier results indicating that antimuscarinic agents suppress REM sleep and increase REM latency. The data, together with the other reported studies, suggest that M1 receptors may also be involved in the regulation of REM sleep in humans. Further studies are needed to clarify the exact functional and anatomical relationship between $\mathrm{M} 1$ and M2 receptors in the regulation of REM sleep.

\section{REFERENCES}

Avissar S, Schreiber G (1989): Muscarinic receptor subclassification and G-proteins: significance for lithium action in affective disorders and for the treatment of the extrapyramidal side effects of neuroleptics. Biol Psychiatry 26:113-130

Burke RE (1986): The relative selectivity of anticholinergic drugs for the M1 and M2 muscarinic receptor subtypes. Mov Disord 1:135-144
Eltze M, Figala V (1988): Affinity and selectivity of biperiden enantiomers for muscarinic receptor subtypes. Eur J Pharmacol 158:11-19

Freedman SB, Beer MS, Harley EA (1988): Muscarinic M1, M2 receptor binding: Relationship with functional efficacy. Eur J Pharmacol 156:133-142

Gillin JC, Sutton L, Ruiz C, Golshan S, Hirsch S, Warmann C, ShiromaniP (1991): Dose dependent inhibition of REM sleep in normal volunteers by biperiden, a muscarinic antagonist. Biol Psychiatr 30:151-156

Grimaldi R, Perucca E, Ruberto G, Gelmi C, Trimarchi F, Hollmann M, Crema A (1986): Pharmacokinetic and pharmacodynamic studies following the intravenous and oral administration of the antiparkinsonian drug biperiden to normal subjects. Eur J Clin Pharmacol 29:735-737

Hobson JA, McCarley RW, Wyzinski PW (1975): Sleep cycle oscillation: Reciprocal discharge by two brain stem neuronal groups. Science 189:55-58

Hobson JA, Lydic R, Baghdoyan HA (1986): Evolving concepts of sleep cycle generation. Behav Brain Sci 9:371-448

Hollmann M, Brode E, Greger G, Müller-Peltzer H, Wetzelsberger $N$ (1984): Biperiden effects and plasma levels in volunteers. Eur J Clin Pharmacol 27:619-621

Hufford CD, Elmarakby SA, Walker LA (1991): Anticholinergic activity of bornaprine and its metabolites in the isolated rat atrium. Pharmacology 42:23-27

Kreiskott H, Kretzschmar R(1985): Neuere pharmakologische Aspekte zu den zentralen Anticholinergika Biperiden und Bornaprin. In: Das Parkinson-Syndrom. Schnaberth G, Auff E (Hrsg) Wissenschaftlicher Dienst Roche, pp 277-287

Larson EW, Pfenning MA, Richelson E (1991): Selectivity of antimuscarinic compounds for muscarinic receptors of human brain and heart. Psychopharmacology 103:162165

Mayo BC, Biggs SR, Chasseaud LF, Hawkins DR, Darragh A, O'Kelly DA (1980): The metabolic fate of Sormodren (bornaprine hydrochloride) in animals and humans. Xenobiotica Vol. 10, No. 12:873-888

Rechtschaffen A, Kales A: A manual of standardized terminology, techniques, and scoring system for sleep stages of human subjects, Department of Health, Education, and Welfare (1968). Washington, DC

Salin-Pascual RJ, Granados-Fuentes D, Galicia-Polo L, Nieves E, Echeverry J (1991): Biperiden administration in normal sleep and after rapid eye movement sleep deprivation in healthy volunteers. Neuropsychopharmacology 5:97-102

Salin-Pascual RJ, Granados-Fuentes D, Galicia-Polo L, Nieves E, Gillin JC (1993): Development of tolerance after repeated administration of a selective muscarinic M1 antagonist biperiden in healthy human volunteers. Biol Psychiatry 33:188-193

Shiromani PJ, Gillin JC, Henriksen SJ (1987): Acetylcholine and the regulation of REM sleep: Basic mechanisms and clinical implications for affective illness and narcolepsy. Ann Rev Pharmacol Toxicol 27:137-156

Syvälahti EKG, Laurén L, Markkanen J, Kunelius R (1987): Interaction of psychotropic drugs with brain muscarinic cholinoceptors: Similarities of biperiden with pirenze- 
pine in receptor binding properties. Pharmacol Toxicol 60:66-69

Syvälahti EKG, Kunelius R, Laurén L (1988): Effects of antiparkinsonian drugs on muscarinic receptor binding in rat brain, heart, and lung. Pharmacol Toxicol 62:90-94

Velazquez-Moctezuma J, Gillin JC, ShiromaniPJ (1989): Effect of specific M1, M2 muscarinic receptor agonists on REM sleep generation. Brain Res 503:128-131
Velazquez-Moctezuma J, Shalauta M, Gillin JC, Shiromani PJ (1990): Differential effects of cholinergic antagonists on REM sleep generation. Psychopharmacol Bull 26: 349-353

Zoltoski RK, Velazquez-Moctezuma J, Shiromani PJ, Gillin JC (1993): The relative effects of selective M1 muscarinic antagonists on rapid eye movement sleep. Brain Res 608:186-190 